\title{
Value of heart-type fatty acid-binding protein (H-FABP) for emergency department patients with suspected acute coronary syndrome.
}

\author{
Karakus Yilmaz Banu ${ }^{1}$ özüçelik doğaç Niyazi², Cevik Erdem³, Doğan Hatice Đpekçi Afşin ${ }^{1}$; Uzun Özlem¹,
} Çelik Yasemin ${ }^{1,}$ Ipekci Afsin ${ }^{4}$

1. Bağcllar Research and Training Hospital, Emergency Department

2. Bakırköy Dr. Sadi Konuk Research and Training Hospital, Emergency

Department

3. Van Military Hospital, Emergency Department

4. Faculty of Cerrahpaşa Medicine, Đstanbul University, Emergency department

\begin{abstract}
:
Objective: The aim of this study is testing the value of H-FABP in the early diagnosis of ACS alone or with routinely used biomarkers such as myoglobin, CK-MB, and c'Tn I in patients who admitted to emergency department (ED) with complaint of chest pain and suspected acute coronary syndrome.

Material and Methods: This prospective and cross-sectional study was performed at the Emergency Department of University hospital between June 2009 and September 2010. Patients who were admitted with chest pain within first 48 hours and suspected ACS were enrolled to the study. Blood samples were taken for CK-MB, myoglobin, cTnI and H-FABP The patients were divided into two groups (ACS and non ACS). Statistical analyse were used for relation of biomarkers with diagnosis of ACS.

Results: A 66 patients were included to the study. H-FAPB values were positive in $15.2 \%$ patients. When H-FABP was added to routinely used biomarkers in the diagnosis of ACS, increasing was observed in all sensitivity, specificity, PPV and NPV values. However, this increase was not stastistically significant.

Conclusion: H-FABP did not provide any significant change in early diagnosis and exclusion of ACS diagnosis when used either alone or combination with routinely used biomarkers
\end{abstract}

Key Words: heart-type fatty acid-binding protein, acute coronary syndrome, biomarker.

DOI: http://dx.doi.org/10.4314/ahs.v14i3.36

\section{Introduction:}

Early diagnosis of acute coronary syndrome (ACS) is essential to prevent major complications and death. Routinely used biomarkers such as myoglobin, MB form of creatine kinase (CK-MB) and cardiac troponin-I (cTn I) can be detected at least 3 hours after chest pain and new biomarkers are needed Recent clinical and experimental studies have suggested that heart-type fatty acid-binding protein (H-FABP) is superior to CK$\mathrm{MB}$ or cardiac troponins in early detection of ischemic myocardial necrosis $(1,2)$. H-FABP is a low molecular weight $(14.5 \mathrm{kDa})$ protein, which contains 132 amino acid residues (3). Fatty acid-binding proteins bind the long-chained fatty acids reversibly and noncovalently, facilitating the intracellular cytoplasmic transport of the fatty acids, and are highly expressed in tissues with ac-

\section{Corresponding author: \\ karakus yilmaz, banu; \\ Bağcılar Research and Training Hospital, \\ Emer gency department}

tive fatty acid metabolism such as the heart muscle $(4,5)$. Its concentration in blood reaches the maximum within 6-8 h and generally decreases within 24-36 h (6). The aim of this study is testing the value of H-FABP in the early diagnosis of ACS alone or with routinely used biomarkers such as myoglobin, CK-MB and cTn I in patients who admitted to emergency department (ED) with complaint of chest pain and suspected acute coronary syndrome.

\section{Material and Methods:}

This prospective and cross-sectional study was performed at the Emergency Department of Bezm-i Alem University between June 2009 and September 2010 after getting approval of ethical committee.

Patients who were admitted with chest pain within first 48 hours and suspected ACS were enrolled to the study. Patients with, renal failure, suspected pulmonary thromboembolism, IM injection history in the last 24 hours and unconscious patients were excluded.

After getting informed consent, chief complaints, 
and history of patients were noted and physical examination were done by researchers. Twelve-lead ECGs were taken in first 10 minutes of admission and blood samples were taken from antecubital vein in first 30 minutes for CK- MB mass, myoglobin, c'TnI and H-FABP. Evaluation and the final diagnosis of patients were done according to ACC/ESC guidelines. $(7,8)$

The patients were divided into two groups. The patients with ST segment elevation on ECG and/or elevated cardiac biomarker levels were taken into group 1 (the patients with ACS diagnosis). The patients with non-specific ECG changes and/or negative cardiac biomarker levels were taken into group 2 (non-ACS diagnosis).

The H-FABP bedside test (Cardiodetect ${ }^{\circledR}$ Rennesens $\mathrm{GmbH}$, Berlin) used in this study is a rapid chromatographic immunotest designed for qualitative determination of H-FABP. It consists of a sample pad (blood separator), a conjugate pad, a nitrocellulose membrane and an absorbent pad incorporated in a test card that has the size of a credit card. Immobilized on the membrane is a test line made of a specific capture monoclonal antibody for H-FABP and a second line, acting as control, consisting of anti-mouse IgG. The test is performed by drawing four drops of capillary whole blood from the patient's blood sample and applying them onto the teststrip. Within 15 minuntes the H-FABP test result (two red lines for elevated plasma H-FABP and one red line for non-elevated plasma H-FABP) can be read.

Miyoglobin, CK-MB and troponin levels were measured at the laboratory of ED with Stratus CS device of Dade Behring Company. Reference range for myoglobin: $9-82 \mathrm{ng} / \mathrm{mL}, \mathrm{CK}-\mathrm{MB}$ mass: 0-3,6 ng/mL, cTnI: 0-0.1 ng/mL (Stratus CS Dade Behring, Germany) and H- FABP: $7 \mathrm{ng} / \mathrm{mL}$ (CardioDetect quant ${ }^{\circledR}$ (Rennesens $\mathrm{GmbH}$, Germany)) were accepted.

Information about prognosis of patients were taken by phone call three months after hospital discharge.

SPSS 15.0 (SPSS Inc, Chicago, IL) and MedCalc 11.3 (MedCalc Software, Mariakerke, Belgium) statistical programmes were used for statistical analyses of data. ROC curve analyse were used for relation of biomarkers with diagnosis of ACS. Chi-square test was used for comparison statistics. Frequency was used for descriptive statistics for categorical variables. Mean \pm SD for continuous variables fit a normal distribution and the median and IQR for variables that do not meet the normal distribution were used. $\mathrm{p}<0.05$ were considered statistically significant.

\section{Results:}

Fifty two $(78.8 \%)$ of 66 patients were male and fourteen $\left(21.2^{\%}\right)$ were female. Mean age of the study population

Table 1 : Demographic Characteristics of the Patients

$$
\text { Total }(n)=66 \quad \text { Group }-\mathrm{I}(\mathrm{n}=36)
$$

(with diagnosis of ACS) Group-2 $(n=30) \quad$ (without ACS)

Mean age

$\% 95$ CI

$58.80 \pm 14.06$

(55.34-62.26)

$59.77 \pm 13.04$

(55.36-64.19)

Male $52(78,8 \%)$

$57.63 \pm 15.34$

(51.90-63.36)

Female 14 (21,2\%)

$29(80.5 \%)$

$23(76.7 \%)$

$7(19,5 \%)$

$7(23.3 \%)$

Typical chest pain34 $(51,5 \%)$

$23(63,9 \%)$

$11(36,7 \%)$

Atypical chest pain32 (48,5\%) $13(36,1 \%)$

$19(63,3 \%)$

DM

$60 \quad 32$

28

HT

IHD

$49 \quad 27$

22

Known CAD

$45 \quad 32$


was $58.80 \pm 14.06$ years (\%95 CI 55.34-62.26, min 29max 88). Demographic characteristics of the patients were summarized in table 1.

H-FAPB values were positive in $10(15.2 \%)$ patients and negative in $56(84.8 \%)$ patients. There was statistically significant difference between group 1 and group 2 in terms of all biochemical markers (Table 2).

When H-FABP was added to routinely used biomarkers in the diagnosis of ACS, increasing was observed

Table 2: Biomarker results of groups

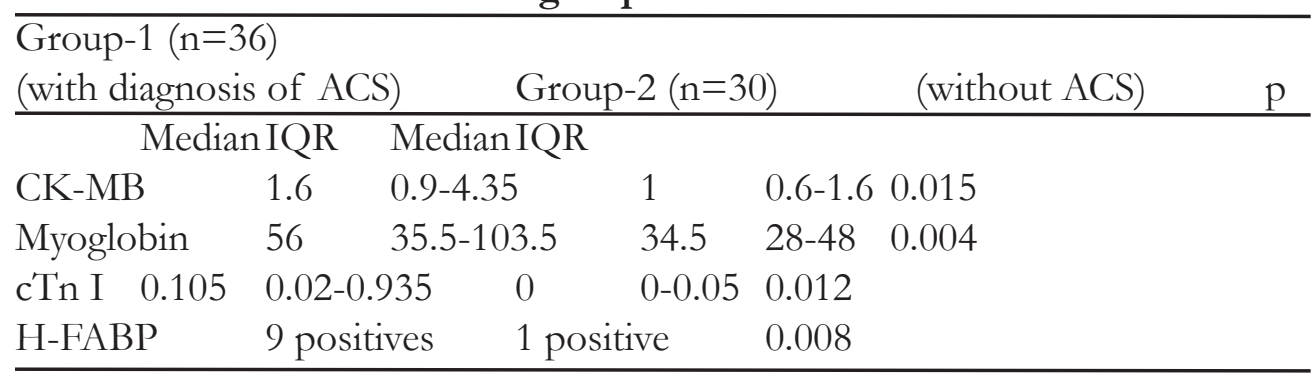

Table 3 : Diagnostic accuracy of biomarkers

\begin{tabular}{|c|c|c|c|c|c|c|c|}
\hline & CK-MB & $\begin{array}{l}\text { CK-MB } \\
+ \text { HFAB }\end{array}$ & cTn I & cTnI +HFAB & Miyoglobin & $\begin{array}{l}\text { Miyoglobin } \\
+\mathrm{HFAB}\end{array}$ & All \\
\hline \multirow{2}{*}{$\begin{array}{l}\text { Sensitivity } \\
\% \text {, } \\
95 \% \mathrm{CI}\end{array}$} & $\begin{array}{c}25 \\
2.12-42.20)\end{array}$ & $\begin{array}{c}36.11 \\
(20.82-53.78)\end{array}$ & $\begin{array}{c}50 \\
(32.9-67,1)\end{array}$ & $\begin{array}{c}52.78 \\
(35.49-69.59)\end{array}$ & $\begin{array}{c}30 \\
(16.35-48.11)\end{array}$ & $\begin{array}{c}41.67 \\
(25.51-59.24)\end{array}$ & $\begin{array}{c}55.56 \\
(38.10-72.06)\end{array}$ \\
\hline & \multicolumn{2}{|c|}{$\mathrm{P}=0.159$} & \multicolumn{2}{|c|}{$\mathrm{P}=0.767$} & \multicolumn{2}{|c|}{$\mathrm{P}=0.157$} & \\
\hline \multirow{2}{*}{$\begin{array}{l}\text { Specificity } \\
\%, \\
95 \% \text { CI }\end{array}$} & $\begin{array}{c}97 \\
(82.8-99.9)\end{array}$ & $\begin{array}{c}93.33 \\
(77.93-99.18)\end{array}$ & $\begin{array}{c}80 \\
(61,4-92,3)\end{array}$ & $\begin{array}{c}76.67 \\
(57.72-90.07)\end{array}$ & $\begin{array}{c}97 \\
(87,8-99,9)\end{array}$ & $\begin{array}{c}93.33 \\
(77.93-99.18)\end{array}$ & $\begin{array}{c}73.33 \\
(54.11-87.72)\end{array}$ \\
\hline & \multicolumn{2}{|c|}{$\mathrm{P}=0.771$} & \multicolumn{2}{|c|}{$\mathrm{P}=0.810$} & \multicolumn{2}{|c|}{$\mathrm{P}=0.771$} & \\
\hline \multirow{2}{*}{$\begin{array}{l}\text { PPV \%, } \\
95 \% \text { CI }\end{array}$} & $\begin{array}{c}90 \\
(55.5-99.8)\end{array}$ & $\begin{array}{c}86.67 \\
(59.54-98.34)\end{array}$ & $\begin{array}{c}75 \\
3,3-90,2)\end{array}$ & $\begin{array}{c}73.08 \\
(52.21-88.43)\end{array}$ & $\begin{array}{c}92 \\
(61,5-99,8)\end{array}$ & $\begin{array}{c}88.24 \\
(63.56-98.54)\end{array}$ & $\begin{array}{c}71.43 \\
(51.33-86.78)\end{array}$ \\
\hline & \multicolumn{2}{|c|}{$\mathrm{P}=0.821$} & \multicolumn{2}{|c|}{$\mathrm{P}=0.863$} & \multicolumn{2}{|c|}{$\mathrm{P}=0.765$} & \\
\hline \multirow{2}{*}{$\begin{array}{l}\text { NPV\%, } \\
95 \% \text { CI }\end{array}$} & $\begin{array}{c}52 \\
(38-65.3)\end{array}$ & $\begin{array}{c}54.90 \\
(40.34-68.87)\end{array}$ & $\begin{array}{c}57 \\
(41-72,3)\end{array}$ & $\begin{array}{c}57.50 \\
(40.89-72.96)\end{array}$ & $\begin{array}{c}54 \\
(39,6-67,4)\end{array}$ & $\begin{array}{c}57.14 \\
(42.21-71.18)\end{array}$ & $\begin{array}{c}57.89 \\
(40.82-73.69)\end{array}$ \\
\hline & \multicolumn{2}{|c|}{$\mathrm{P}=0.771$} & \multicolumn{2}{|c|}{$\mathrm{P}=0.925$} & \multicolumn{2}{|c|}{$\mathrm{P}=0.775$} & \\
\hline $\begin{array}{l}\mathrm{LR}(+) \\
95 \% \mathrm{CI}\end{array}$ & 7.5 & $\begin{array}{c}5.42 \\
(1.33-22.13)\end{array}$ & $\begin{array}{c}2.50 \\
(1,14-5,49)\end{array}$ & $\begin{array}{c}2.26 \\
(1.10-4.64)\end{array}$ & $\begin{array}{c}9.17 \\
(1,25-66,99)\end{array}$ & $\begin{array}{c}6.25 \\
(1.55-25.18)\end{array}$ & $\begin{array}{c}2.08 \\
(1.08-4.04)\end{array}$ \\
\hline $\begin{array}{l}\mathrm{LR}(-) \\
95 \% \mathrm{CI}\end{array}$ & $\begin{array}{c}0.78 \\
(0.64-0.95)\end{array}$ & $\begin{array}{c}0.68 \\
(0.53-0.89)\end{array}$ & $\begin{array}{c}0.62 \\
(0,43-0,91)\end{array}$ & $\begin{array}{c}0.62 \\
(0.41-0.92)\end{array}$ & $\begin{array}{c}0.72 \\
(0,57-0,90)\end{array}$ & $\begin{array}{c}0.62 \\
(0.47-0.84)\end{array}$ & $\begin{array}{c}0.61 \\
(0.40-0.93\end{array}$ \\
\hline
\end{tabular}

in all sensitivity, specificity, PPV and NPV values. However, this increase was not stastistically significant

(Table 3).

AUC value of H-FABP in the diagnosis of ACS was 0,61 (95\%CI; 0,48 - 0,73) and c'Tn I was 0,51 (95\%CI; $0,52-0,76)$ (Figure 1).

$\mathrm{H}$-FABP reaches the highest concentration in four hours after cardiac injury. H-FAPB values were positive in $10 \%(n=5)$ of 50 patients who admitted to the emergency department within four hours of chest pain and $31,3 \% \quad(n=5)$ of 16 patients who admitted to the emergency department more than 4 hours. There was a stastistically significant difference between first 4 hours admission and more than 4 hours admission in terms of positively of $\mathrm{H}-\mathrm{FABP}(\mathrm{p}<0,05)$.

Figure 1: ROC curve analysis of $\mathrm{H} \mathrm{FAB}$ and cTn 1 in diagnosis of ACS

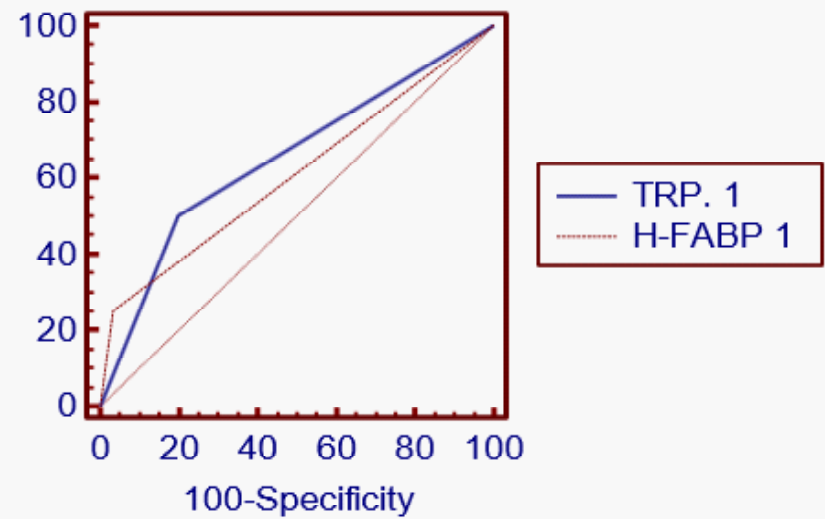


Forty-eight patients $(72,7 \%)$ were reached by phone three months after hospital discharge. There was no mortality and morbidity $72,2 \%(n=26)$ of group 1 and $53,3 \%(n=16)$ of group 2 and $13,9 \%(n=5)$ of group 1 and $3,3 \%(n=1)$ of group 2 were died.

\section{Discussion}

Chest pain creates $5 \%$ of all ED admissions. Significant portion of the patients admitted to the emergency department with chest pain get diagnosis of ACS. $15 \%$ of admissions to the ED with chest pain are diagnosed with ACS $(9,10)$. Patients are admitted to the ED without chest pain (47\%), pricking and piercing chest pain $(22 \%)$, and pleuritic chest pain $(6 \%)$ (11). In our study ACS prevalence was high. Patients suspected of having ACS were enrolled to the study and ACS prevalence was higher than literature. Liao et al (12) reported that $73 \%(n=74)$ of patients (with chest pain?) received a diagnosis of AMI; the mean age of patients was 69.0 years, and $70 \%$ of the study population was male. In our study,

$54.5 \%$ of patients who were admitted to ED with chest pain were diagnosed with ACS; the mean age was 59.8 years, and $78.8 \%$ were male. Early diagnosis of AMI affects mortality directly; thus, biochemical biomarkers have been examined with regard to faster and more accurate diagnoses of AMI $(12,13)$.

Several studies have shown that sensitivity and specificity of H-FABP ranged from 39 to $78.5 \%$ and $78.2-94 \%$, respectively in early diagnosis of ACS (14-20). Orak et al (18) was found 98\% specificity and $71 \%$ sensitivity different from those study. The most important cause of the different results in these studies which used qualitative techniques is thought to be the low cut-off levels. $100 \%$ sensitivity and $27-38 \%$ specificity were found in two studies which used quantitative H-FABP measurements like our study $(21,22)$. Results of our study were consistent with literature which used quantitative $\mathrm{H}$ FABP measurement. In addition, PPV and NPV values of our study were consistent with $63-100 \% \mathrm{PPV}$ and $47-97 \%$ NPV values of literature $(21,22)$.

Diagnostic accuracy (AUC) of $\mathrm{H}$ - FABP ranges from 0,65 to 0,83 in the literature $(15,17)$. In one study, AUC was determined as 0,967 , but this is considered to low cut-off value (18). In our study, the AUC values were consistent with the results of the literature.

Freund et al (17) found that sensitivity, specificity, PPV and NPV values of troponin were $71 \%, 97 \%, 78 \%$ and $95 \%$ respectively and these values were $80 \%, 85 \%, 46 \%$ and $96 \%$ for troponin used together with H-FABP. Mc Mahon et al (23) found that sensitivity, specifi- city, PPV and NPV values of troponin within first six hours were $67.6 \%, 94.3 \%, 66 \%$ and $95 \%$ respectively, and these values were $88.2 \%, 86.8 \%, 52 \%$ and $98 \%$ for troponin used together with H-FABP.

Sensitivity, specificity, PPV and NPV values were 67.6\%, $94.3 \%, 66 \%$ and $95 \%$ respectively for CK-MB, $88.2 \%$, $86.8 \%, 52 \%$ and $98 \%$ respectively for CK-MB used together with H-FABP and $88.2 \%, 84.9 \%, 48 \%$ and $98 \%$ respectively for CK-MB, myoglobin and $\mathrm{H}-\mathrm{FABP}$ used together (23). In our study, H-FABP increases sensitivity, specificity, PPV and NPV values of routinely used biomarkers in order to increase the likelihood of an accurate diagnosis, but this increase was not stastistically significant. In our study, specificity, sensitivity, PPV, NPV values were lower than other studies. The reason of different from literatures could be the variable time elapsed from the beginning of the pain until emergency department.

Okomato (24) and Orak (18) et al concluded that CKMB is less helpfull than H- FABP in early diagnosis of ACS. According to Orak et al (18) this difference was derived from cut- off value and method which used for H-FABP measurement. Slot et al (14) reported that $\mathrm{H}-\mathrm{FABP}$ is not ideal test and has high false negativity, also is not appropriate for exclusion of a disease with high morbidity and mortality such as ACS. In our study, CK-MB and H-FABP was not superior to each other in early diagnosis of ACS. In addition, specificity and PPD of H-FABP results were better than cTn I results on admission. When compared CK-MB, H- FABP did not show significant contribution to early diagnosis of ACS.

\section{Limitations}

The most important limitation of our study is the low number of cases and to be a single center trial. Ischemic type chest pain was used to selection of the patients and this was a limitation in terms of homogenization. Quantitative measurement of H-FABP in our study was the other limitation.

\section{Conclusion}

Consequently we did not found significant change in early diagnosis and exclusion of ACS diagnosis when used either alone or combination with routinely used biomarkers such as myoglobin, CK-MB and cTnI. Further studies with large study population should be performed.

\section{References}

1. Nakata T, Hoshimoto A, Hase M, Tsuchihashi K, 
Shimamoto K. Human heart-type fatty acid-binding protein as an early diagnostic and prognostic marker in acute coronary syndrome. Cardiology 2003;99(2):96104.

2. Aartsen WM, Pelsers MM, Hermens W'T, Glatz JF, Daemen MJ, Smits JF. Heart fatty acid binding protein and cardiac troponin $T$ plasma concentrations as markers for myocardial infarction after coronary artery ligation in mice. Eur J Physiol 2000;439(4):416-22.

3. Schreiber A, Specht B, Pelsers MM, Glatz JF, Börchers T, Spener F. Recombinant human heart type fatty acid binding protein as standard immunochemical assays. Clin Chem Lab Med 1998;36(5):283-8.

4. Glatz JFC, Vandervuss GJ. Cellular fatty acid binding proteins: their function and physiological significance. Prog Lipid Res 1996;35(3):243-82.

5. Kragten JA, Van Nieuwenhoven FA, Van Dieijen-Visser MP, Theunissen PH, Hermens W'T, Glatz JF. Distribution of myoglobin and fatty acid binding protein in human cardiac autopsies. Clin Chem 1996;42(2):337-8.

6. Van Nieuwenhoven FA, Kleine AH, Wodzig WH, Hermens WT, Kragten HA, Maessen JG, et al. Discrimination between myocardial and skeletal muscle injury by assessment of the plasma ratio of myoglobin over fatty acid binding protein. Circulation 1995;92(10):2848-54.

7. Bassand JP, HammCW, Ardissino D, et al. Guidelines for the diagnosis and treatment of non-ST-segment elevation acute coronary syndromes. Eur Heart J 2007;28: 1598-660.

8. Anderson JL, Adams CD, Antman EM, et al. ACC/AHA 2007 guidelines for the management of patients with unstable angina/non-ST-Elevation myocardial infarction: a report of the American College of Cardiology/American Heart Association Task Force on Practice Guidelines (Writing Committee to Revise the 2002 Guidelines for the Management of Patients With Unstable Angina/Non-ST-Elevation Myocardial Infarction) developed in collaboration with the American College of Emergency Physicians, the Society for Cardiovascular Angiography and Interventions, and the Society of Thoracic Surgeons endorsed by the American Association of Cardiovascular and Pulmonary Rehabilitation and the Society for Academic Emergency Medicine. J Am Coll Cardiol 2007;50:e1-157.

9. Tintinalli JE, Kelen GD, Stapczynski JS: Cardiovascular disease: Chest Pain: Cardiac or Not. Emergency Medicine: A Comprehensive Study Guide. 7th ed. North Carolina: McGraw-Hill; 2010. p.361-7.

10. Green GB, Hill PM. Cardiovascular disease:
Acute Coronary Syndromes: Acute Myocardial Infarction and Unstable Angina. In; Tintinalli JE, Kelen GD, Stapczynski JS (eds). Emergency Medicine: A Comprehensive Study Guide, 7th ed. North Carolina: McGraw-Hill; 2010. P.367-385..

11. Gupta M, Tabas JA, Kohn MA. Presenting complaint among patients with myocardial infarction who present to an urban, public hospital emergency department. Ann Emerg Med

2002;40(2):180-6.

12. Liao J, Chan CP, Cheung YC, Lu JH, Luo Y, Cautherley GW, et al. Human heart-type fatty acid-binding protein for on-site diagnosis of early acute myocardial infarction. Int J Cardiol 2009;133(3):420-3.

13. Dekker MS, Mosterd A, van 't Hof AW, Hoes AW. Novel biochemical markers in suspected acute coronary syndrome: systematic review and critical appraisal. Heart 2010;96(13):1001-10.

14. Bruins Slot MH, Rutten FH, van der Heijden GJ, Doevendans PA, Mast EG, Bredero AC, et al. Diagnostic value of a heart-type fatty acid-binding protein $(\mathrm{H}-$ FABP) bedside test in suspected acute coronary syndrome in primary care. Int J Cardiol 2013;

15. Inoue K, Suwa S, Ohta H, Itoh S, Maruyama S, Masuda N, et al. Heart Fatty Acid- Binding Protein Offers Similar Diagnostic Performance to High-Sensitivity Troponin $\mathrm{T}$ in Emergency Room Patients Presenting With Chest Pain. Circ J 2011;75(12):2813-20.

16. Kehl DW, Igbal N, Fard A, Kipper BA, De La Parra Landa A, Maisel AS. Biomarkers in acute myocardial injury Transl Res 2012;159(4):252-64.

17. Freund Y, Chenevier-Gobeaux C, Leumani F, Claessens YE, Allo JC, Doumenc B, et al. Heart-type fatty acid binding protein and the diagnosis of acute coronary syndrome in the ED. Am J Emerg Med 2012;30(8):1378-84.

18. Orak M, Ustündağ M, Güloğlu C, Ozhasenekler A, Alyan O, Kale E. The role of the heart-type fatty acid binding protein in the early diagnosis of acute coronary syndrome and its comparison with troponin I and creatine kinase-MB isoform. Am J Emerg Med 2010;28(8):891-6.

19. Alhashemi JA. Diagnostic accuracy of a bedside qualitative immunochromatographic test for acute myocardial infarction. Am J Emerg Med 2006;24(2):149_ 55.

20. Valle HA, Riesgo LG, Bel MS, Gonzalo FE, SanchezMS, Oliva LI. Clinical assessment of hearttype fatty acid binding protein in early diagnosis of acute coronary syndrome. Eur J Emerg Med 2008;15(3):140-4.

African Health Sciences Vol 14 Issue 3, September 2014 
21. Rosman J, Kavala G, Obunai K, Bergmann SR. The role of heart-type fatty acid- binding protein in the diagnosis of acute coronary syndrome. Int J Angiol 2009;18(2):79-81.

22. Ruzgar O, Bilge AK, Bugra Z, Umman S, Yilmaz

$\mathrm{E}$, Ozben B, et al. The use of human heart-type fatty acid-binding protein as an early diagnostic biochemical marker of myocardial necrosis in patients with acute coronary syndrome, and its comparison with troponin-T and creatine kinase-myocardial band. Heart Vessels 2006;21(5):309-14.
23. McMahon CG, Lamont JV, Curtin E, McConnell RI, Crockard M, Kurth MJ, et al. Diagnostic accuracy of heart-type fatty acid-binding protein for the early diagnosis of acute myocardial infarction. Am J Emerg Med 2012;30(2):267-74.

24. Okamoto F, Sohmiya K, Ohkaru Y, Kawamura K, Asayama K, Kimura $H$, et al. Human heart type cytoplasmic fatty acid binding protein fort he diagnosis of acute myocardial infarction. Clinical evaluation of H-FABP in comparison with myoglobin and creatine kinase isoenzyme MB. Clin Chem Lab Med 2000;38(3):231-8. 